\title{
EVALUATION OF ANTIBACTERIAL PROPERTIES OF SOME MEDICINAL PLANTS USED FOR THE TREATMENT OF RESPIRATORY TRACT INFECTIONS IN NEPAL

\author{
Rup Bahadur Kunwor* \\ Olivia Thapa
}

\begin{abstract}
The present work was designed to evaluate the antibacterial properties of the ethanol extracts of five selected medicinal plants Azadirachta indica, Ocimum sanctum, Jasminium humile, Glycyrrhiza glabra and Acorus calamus on bacteria causing respiratory tract infections. Almost all the tested medicinal plants showed inhibitory effect against the test organisms. Among the medicinal plants evaluated Ocimum sanctum was found effective against most of the test organisms except Pseudomonas aeruginosa.

The growth of Staphylococcus aureus was inhibited by all tested plant extracts with highest zone of inhibition by G. glabra with ZOI value $23 \mathrm{~mm}$ and $M B C$ value $0.39 \mathrm{mg} / \mathrm{ml}$ in ethanol suspension. Among the test organisms $K$. pneumoniae was found more resistant towards the test plant extracts. This bacterium was inhibited only by J. humile with ZOI value $13 \mathrm{~mm}$ and MBC value $6.25 \mathrm{mg} / \mathrm{ml}$ in alcohol solution.

The present work evidently provides information on the role of some medicinal plants in the fight against bacteria causing respiratory tract infections.
\end{abstract}

Key words: Medicinal plants, Antibacterial activity, Zone of Inhibition (ZOI), Minimum Bactericidal Concentration (MBC), Plant extracts.

\section{INTRODUCTION}

Plants have been in use for medicinal purposes from the beginning of human civilization. Antiquities of medicinal herbs are to be traced back as far as the Vedic period, 4500 B.C. to 1600 B.C. Ayurveda, the science of life in Hinduism, remains to be the main source of medicinal knowledge and skill in most part of South Asia including Nepal. Vaidhyas and Kabirajs followed Ayurveda in their pursuit of knowledge and practice in medicine (IUCN, 2000). After a period of decline of these traditional system, "green medicine" are once again back to the center stage of our health programs (Sivaranjan and Balchandran, 1994)

More than 35,000 plants species are being used in various human culture around the world for medicinal purposes (Lewinton, 1993). The main reasons for the widespread use of medicinal plants are: they are reliable and effective in treating and preventing diseases, less toxic than chemically synthesized medicines, have easy access to people living in rural areas and cheaper (WHO, 1989).

Mr. Kunwor is a Lecturer, Department of Microbiology, Amrit Campus, T.U., Kathmandu, Nepal. 
Since, Himalayas are considered the big store house of enormous important plants and Nepal Himalayas representing the central Himalaya provide shelters to a large number of species distributed from very few meters to around 5000 meters above sea level. Great range of bioclimatic variation from tropical to alpine zones brings richness in biological diversity in Nepal (Joshi and Joshi, 2001). Majority of people in Nepal (approximately 85\%) particularly living in rural areas depend directly or indirectly on traditional medicines based on herbal drugs. Since there are many barriers to access health centers, doctors and allopathic medicines as well as lack of facilities, inaccessibility and expense (Mills, 1994 and Taylor et al., 1996).

Infectious diseases affecting the respiratory tract represent critical problem to health. These infections are common ailments among the people living in rural as well as urban areas of Nepal. People suffer from these infections one or more in their lifetime. They usually treat these diseases by use of traditional herbs. The most common etiological agents for the respiratory tract infections are Streptococcus pyogens, Haemophilus influenza, Staphylococcus aureus, Pneumococci, Pseudomonas aeruginosa, Rhino virus, Influenza virus etc.

It is very important to carry out research on effect of medicinal plants on microorganisms to fulfill the demand of alternative medicinal treatment as well as to know the efficacy of such plants which people have been using since ancient times. If local knowledge of medicinal herbs is thoroughly and scientifically explored, this would undoubtedly be significant in finding the way of medications and cost of medicines may become cheaper, which could be sold within the country and possibly exported, which may be helpful to raise the socioeconomic conditions of the people and nation.

\section{METHODS AND MATERIALS}

\section{Plant MATERIALS AND EXTRACTION}

Five plant species used in this work were collected from different parts of Nepal. The collected plant materials were leaves of Azadirachta indica (Neem), Ocimum sanctum (Tulsi), Jasminium humile (Jai), rhizomes of Glycyrrhiza glabra (Jethimadhu) and Acorus calamus (Bojho). The plants were identified by experts from Central Department of Botany, Tribhuvan University, Nepal. The extracts were obtained by Soxhlet extraction by Ethanol (Tewari et al., 1992, Shale et al., 1999 and Thomas et al., 1999).

\section{PREPARATION OF STOCK/WORKING SOLUTIONS}

$100 \mathrm{mg} / \mathrm{ml}$ of each crude extract was made by taking $1 \mathrm{gm}$ of extract in $9 \mathrm{ml}$ of each solventie. distilled water, dimethyl methyl solfoxide, methanol and ethanol in clean and capped test tubes. The solution was dissolved by vortexing. After making stock/working solution the test tubes were capped, sealed and stored in refrigerator until use.

\section{BACTERIAL STRAINS AND PREPARATION OF STANDARD CULTURE INOCULUM}

The studied microorganisms included Staphylococcus aureus, Streptococcus pneumoniae, Streptococcus pyogenes, Klebsiella pneumoniae and Pseudomonas aeruginosa. The bacterial cultures were obtained from Kathmandu 
Model Hospital. The culture inoculum was prepared by comparing the bacterial broth with 0.5 McFarland Standard WHO (1991).

\section{SCREENING AND EVALUATION OF ANTIMICROBIAL ACTIVITY}

The screening and evaluation of antimicrobial activity was performed by two methods Viz. agar well diffusion method and two fold broth dilution method (Dubey and Maheshwari, 2013). The diameter of zone of inhibition (ZOI) produced by plants extract on particular microorganisms was measured for the estimation of potency of that medicinal plant extract. Similarly, two fold broth dilution methods were applied for the determination of minimum bactericidal concentration (MBC). All the procedures were performed in triplicates.

\section{RESULT}

Antimicrobial activities of the plant extract under investigation were evaluated by two methods viz. agar well diffusion and two fold serial dilution methods. The diameter of ZOI given by plant extract against the test bacteria was measured for the estimation of potency of the particular extract. Similarly, the minimum bactericidal concentration (MBC) was also determined.

The ZOI and MBC of the extracts on different test organisms are illustrated in Table 1. Among the plant extracts, $O$. sanctum inhibited the growth of 4 test organisms except K. pneumoniae, which was followed by G. glabra and J. humile. G. glabra and J. humile inhibited 3 out of five test organisms. G. glabra inhibited the growth of $S$. aureus, $S$. pyogens and $S$. Pneumoniae with highest ZOI and MBC values of $23 \mathrm{~mm}$ and $0.39 \mathrm{mg} / \mathrm{ml}$ respectively in ethanol suspension towards $S$. aureus. J. humile was also found effective against S. aureus, S. pyogens and $K$. pneumoniae with highest ZOI $16 \mathrm{~mm}$ against $S$. pyogens in both ethanol and methanol suspension. A. calamus inhibited only $S$. aureus and $S$. pyogens and $A$. indica was effective against only with $S$. aureus and $P$. aeruginosa.

S. aureus was found sensitive to all plant extracts and the highest ZOI of value $23 \mathrm{~mm}$ was observed in G. glabra in ethanol suspension. Among the test organisms, $K$. pneumoniae was found more resistant towards the evaluated plant extracts. It was inhibited only by $J$. humile with highest ZOI and MBC values 13 $\mathrm{mm}$ and $6.25 \mathrm{mg} / \mathrm{ml}$ respectively in ethanol suspension.

Table 1: Antimicrobial activity of the studied plant extracts on test organisms

\begin{tabular}{|c|c|c|c|c|c|c|c|c|c|c|c|}
\hline \multirow{3}{*}{$\begin{array}{l}\mathrm{S} . \\
\mathrm{N} .\end{array}$} & \multirow{3}{*}{$\begin{array}{c}\text { Plant } \\
\text { extracts }\end{array}$} & \multicolumn{10}{|c|}{ Antimicrobial activity } \\
\hline & & \multicolumn{2}{|c|}{ S. aureus } & \multicolumn{2}{|c|}{ S. pneumoniae } & \multicolumn{2}{|l|}{ S. pyogens } & \multicolumn{2}{|c|}{ K. pneumoniae } & \multicolumn{2}{|c|}{ P. aeruginosa } \\
\hline & & $\begin{array}{l}\text { ZOI } \\
(\mathrm{mm})\end{array}$ & $\mathrm{MBC}$ & $\begin{array}{l}\text { ZOI } \\
(\mathrm{mm})\end{array}$ & $\mathrm{MBC}$ & $\begin{array}{l}\text { ZOI } \\
(\mathrm{mm})\end{array}$ & $\mathrm{MBC}$ & $\begin{array}{l}\text { ZOI } \\
(\mathrm{mm})\end{array}$ & $\mathrm{MBC}$ & $\begin{array}{l}\begin{array}{l}\text { ZOI } \\
(\mathrm{mm})\end{array} \\
\end{array}$ & $\mathrm{MBC}$ \\
\hline 1. & A.calamus & 12(E) & 6.25 & - & - & $20(\mathrm{E})$ & 6.25 & - & - & - & - \\
\hline 2. & A. indica & $15(\mathrm{M})$ & 6.25 & - & - & - & - & - & - & $15(\mathrm{E})$ & 6.25 \\
\hline 3. & G. glabra & $23(\mathrm{E})$ & 0.39 & $14(\mathrm{E})$ & 6.25 & $17(\mathrm{D} / \mathrm{W})$ & 12.5 & - & - & - & - \\
\hline 4. & J. humile & 13(E) & 6.25 & - & - & $16(\mathrm{E}) /(\mathrm{M})$ & 6.25 & 13(E/M) & 6.25 & - & - \\
\hline 5. & O. sanctum & $16(\mathrm{M})$ & 6.25 & $14(\mathrm{M})$ & 6.25 & $22(\mathrm{D} / \mathrm{W})$ & 6.25 & - & - & $19(\mathrm{E})$ & 25 \\
\hline
\end{tabular}

Note: $(\mathrm{E})=$ plant extract suspension in Ethanol, $(\mathrm{M})=$ plant extract suspension in methanol

$(D / W)=$ plant extract suspension in distilled water 


\section{DISCUSSION}

Antibacterial activities of five medicinal plants were evaluated in the laboratory. These medicinal plants have been using for the treatment of respiratory tract diseases in Nepal since ancient times. The organisms which were tested against these medicinal plants were S. aureus, S. pneumoniae, S. pyogens, $K$. pneumoniae and $P$. aeruginosa. Almost all the tested medicinal plants showed some degree of inhibitory effect against the test organisms. Among the medicinal plants evaluated $O$. sanctum was found effective against most of the test organisms with highest zone of inhibition $22 \mathrm{~mm}$ in D/W suspension towards $S$. pyogens. The minimum bactericidal concentration of $O$. sanctum was found 6.25 $\mathrm{mg} / \mathrm{ml}$ with $S$. aureus, S. pneumoniae and S. pyogens. However, $P$. aeruginosa was found resistant towards the extracts of $O$. sanctum

The growth of $S$. aureus was inhibited by all the plant extracts tested with highest zone of inhibition by G. glabra with ZOI value $23 \mathrm{~mm}$ and MBC value $0.39 \mathrm{mg} / \mathrm{ml}$ in ethanol suspension. This is followed by $O$. sanctum, $A$. indica, J. humile and A. calamus with ZOI values $16 \mathrm{~mm}, 15 \mathrm{~mm}, 13 \mathrm{~mm}$ and 12 $\mathrm{mm}$ respectively. Among the test organisms K. pneumoniae was found more resistant towards the test plant extracts. This bacterium was inhibited by only $J$. humile with ZOI value $13 \mathrm{~mm}$ and $\mathrm{MBC}$ value $6.25 \mathrm{mg} / \mathrm{ml}$ in alcohol solution.

A. calamus inhibited only two microorganisms $S$. aureus and $S$. pyogens. This is in accordance with Zabia et.al., (1999) where the ethanolic extracts of $A$. calamus demonstrated only moderate antibacterial activity. Similar antibacterial activity was observed by Gautam(2002) with A. calamus.

Meanwhile, G. glabra produced ZOI against all Gram-positive bacteria and no inhibitory effect on Gram-negative bacteria tested. This result is quite similar to Devkota et al., (1999) who reported the crude ethanol extracts of $G$. glabra showed best antibacterial activity against all tested bacterial strains. Pokhrel (2000) in his study also found that G. glabra more active towards Grampositive than Gram-negative bacteria.

The study results bolster the existing knowledge of Nepalese people on medicinal plants. The pharmaceutical companies can take advantage from the current research results to produce herbal medicines which can be used for the treatment of Respiratory Tract Infections. Furthermore, the economic status of the people can be upgraded by cultivating and exporting medicinal plants. Besides, health of people can be protected from adverse effect of allopathic medicines by consuming herbal medicines.

Furthermore, plants which showed higher antimicrobial activity should be analyzed in detail to identify the active antimicrobial constituents and also their mode of action. In addition, medicinal plants should also assayed against microorganisms that are not included here, especially those that are of public concern such as HIV, Hepatitis virus, Fungi as well Multidrug Resistant bacteria. 


\section{CONCLUSION}

The present work evidently provides information on the effect of some medicinal plants against bacteria causing Respiratory tract infections. The study also highlights the potential of the tested medicinal plants as strong antibacterial agent.

\section{ACKNOWLEDGMENTS}

We are grateful to Prof. Dr. Shital Raj Basnyat, Central Department of Microbiology and Dr. Kayo Devi Yami, Former Chief, Science and Technology Faculties, NAST for their kind supervision. We are immensely thankful to Prof. Dr. Anjana Singh, Head of Central Department of Microbiology, Tribhuvan University. Lastly we would like to thank all the staffs of NAST and Central Department of Microbiology for their assistance during laboratory work.

\section{WORKS CITED}

Devkota, K.P., Acharya, R., Baral, M.P. and Adhikari, R.P. (1999). Antimicrobial activities of some herbal plants used in traditional medicine in Nepal. In: Proceedings of Third National Conference on Science and Technology, NAST, Kathmandu, Nepal, pp. 1331-1317.

Dubey, R.C. and Maheshwari, D.K. (2013). A text book of Microbiology, Revisededn, S. Chand and Company Ltd.

Gautam, S. (2002). Medicinal plants used to treat respiratory complaints in Nawalparasi District (Southern Nepal) and their antibacterial activities. M.Sc. Dissertation, Central Department of Botany, Kirtipur, Kathmandu, Nepal.

IUCN (2000). National register of medicinal plants and aromatic plants, IUCN. The World Conservation Union Kathmandu, Nepal, 13: 200-202.

Joshi, K.K. and Joshi, S.D. (2001). Genetic heritage of medicinal and aromatic plants of Nepal Himalayas. Buddha Academic Publishers and Distributors, Pvt. Ltd. Kathmandu, Nepal.

Lewington, A. (1993). Medicinal plant and plant Extracts: A review of their importation into Europe. Traffic International, Cambridge, U.K.

Mills, S. (1994). The complete guide to modern herbalism. Thorsons, Harper Colins Publishers, London.

Pokhrel, N.R. (2000). Screening and evaluation of the antimicrobial activity of some medicinal plants of Nepal and isolation of pure antimicrobial compound from Bauhinia variegata. M.Sc. Dissertation, Central Department of Microbiology, Tribhuvan University, Nepal.

Shale, T.L., Strik, W.A. and Staden, J.V. (1999). Screening of medicinal plants used in Lesotho for antibacterial and anti-inflammatory activity. Journal of Ethnopharmacolog, .67(3): 347-354.

Sivaranjan, V.V. and Balchandran, I. (1994). Ayurvedic drugs and their plant sources. Oxford and IBH Publishing Company, New Delhi, India. 
Taylor, R.S.L., Edel, F., Manandhar N.P. and Towers, G.H.N. (1996). Antimicrobial activities of southern Nepalese medicinal plants. Journal of Ethnopharmacology, 50:97-102.

Tewari, K.S., Malhotra, S.N., and Vishnoi, N.K. (1992). A textbook of Organic Chemistry, $2^{\text {nd }}$ Reprint edn. Vikash Publishing House Pvt. Ltd.

Thomas, E., Shanmugham, J. and Raf, M.M. (1999). Invitro antimicrobial activity of certain medicinal plants .Biomedicine. 19(3):185-190.

WHO (1989). Medicinal Plants in China. WHO Regional Publications. Western Pacific Series No.2.

WHO (1991). Basic Laboratory Procedure in Clinical Bacteriology. World Health Organization. Geneva.

Zaiba, I.A., Beg, A.Z. and Mahmood, Z. (1999). Potency of selected medicinal plants with special interest in activity against phytopathogenic fungi. India Veterinary Journal. 24(4): 299-306. 